\title{
ANALISIS PENGARUH GOOD CORPORATE GOVERNANCE TERHADAP CORPORATE SOCIAL RESPONSIBILITY
}

\author{
EDDY R. SEMBIRING
}

Fakultas Ekonomi Program Studi Akuntansi Universitas Katolik Santo Thomas eddy.r.sembiring@gmail.com

\begin{abstract}
ABSTRAK
Tujuan penelitian ini adalah untuk menganalisis pengaruh mekanisme corporate governance terhadap pengungkapan corporate sosial responsibility perusahaan dalam laporan tahunan perusahaan yang terdaftar di Bursa Efek Indonesia. Mekanisme corporate governance diproksikan dengan ukuran dewan komisaris, proporsi direktur independen, proporsi direktur perempuan, konsentrasi kepemilikan dan proporsi komisaris independen. Populasi dalam penelitian ini adalah seluruh perusahaan yang terdaftar di Bursa Efek Indonesia ada tahun 2018.Sampel ditetapkan dengan teknik purposive sampling yakni 41 perusahaan dari sector pertambangan.Pengumpulan data dilakukan dengan teknik dokumentasi. Teknik analysis yang digunakan adalahModel regresi linear berganda.Hasil penelitian ini menunjukkan bahwa secara simultan variabel ukuran dewan komisaris, direktur independen, direktur perempuan, konsentrasi kepemilikan dan Komisaris independen mempunyai pengaruh yang signifikan tehadap pengungkapan tanggung jawab sosial perusahaan, sedangkan secara parsial hanya variabel ukuran dewan komisaris yang berpengaruh signfikan terhadap pengungkapan tanggung jawab sosial peusahaan, sedangkan variabel direktur independen, direktur perempuan, konsentrasi kepemilikan dan Komisaris independen mempunyai pengaruh yang tidak signifikan.
\end{abstract}

Kata Kunci: corporate governance, corporate sosial responsibility, dewan komisaris, direktur independen, direktur perempuan, konsentrasi kepemilikan dan komisaris independen

\section{PENDAHULUAN :}

Masyarakat dan perusahaan merupakan dua entitas yang tidak dapat dipisahkan.Dalam upaya menjaga kelangsungan hidupnya, perusahaan sangat tergantung pada masyarakat.Selain sebagai anggota lingkungan dimana perusahaan beroperasi, masyarakat juga menjadi pelanggan dan penyedia tenaga kerja bagi perusahaan.Masyarakat juga sangat membutuhkan perusahaan untuk mencukupi kebutuhannya dan tempatnya mencari nafkah.Jadi ada hubungan timbal balik antara keduanya. Keharmonisan hubungan antara perusahaan dan masyarakat akan memberi kontribusi yang besar dalam perkembangan suatu negara.

Dua aspek penting harus diperhatikan agar tercipta kondisi sinergis antara perusahaan dan masyarakat, sehingga keberadaan perusahaan dapat membawa perubahan ke arah perbaikan dan peningkatan taraf hidup 
masyarakat.Aspek yang pertama aspek ekonomi yaitu perusahaan harus berorientasi mendapatkan keuntungan.Aspek yang kedua adalah sosial, dimana perusahaan harus memberikan kontribusi secara langsung kepada masyarakat dan lingkungan. Salah satu cara untuk menciptakan kondisi sinergis antara perusahaan dan masyarakat yaitu dengan menerapkan corporate social responsibility(CSR).

Pengungkapan tanggung jawab sosial perusahaan yang sering juga disebut sebagai social disclosure, corporate social reporting, social accounting (Mathews (1995), atau corporate social responsibility (Hackston dan Milne, 1996) merupakan proses pengkomunikasian dampak sosial dan lingkungan dari kegiatan ekonomi organisasi terhadap kelompok khusus yang berkepentingan dan terhadap masyarakat secara keseluruhan. Hal tersebut memperluas tanggung jawab perusahaan, di luar peran tradisionalnya untuk mencari laba untuk pemegang saham.

Ada dua pandangan berbeda tentang keberadaannya. Yang pertama didasarkan pada teori keagenan (Jensen, M.; Meckling, W, 1976) dan yang kedua adalah teori stake holders. Menurut Barnea dan Rubin (2010) keterlibatan CSR adalah hubungan keagenan antara manajemen puncak dan pemegang saham. Mereka berpendapat bahwa manajemen puncak harus memiliki kepedulian pribadi dalam berinvestasi melalui keterlibatan CSR, dalam kegiatan untuk membangun reputasi sebagai warga negara yang baik dan bertanggung jawab secara sosial. Manajer puncak yang kadang terlalu percaya diri ini dapat menghancurkan nilai investasi sehingga pengendalian proaktif dengan menggunakan metode corporate governance yang berbeda untuk mengurangi kemungkinan investasi berlebihan dalam keterlibatan CSR.

Pandangan kedua adalah bahwa, karena mungkin tidak mudah untuk meyakinkan semua stakeholders terkait, ada peningkatan jumlah literatur tentang resolusi konflik berdasarkan teori stake holders di mana tanggung jawab perusahaan adalah untuk menjaga kesejahteraan stake holders. Manajemen puncak dapat menggunakan mekanisme corporate governance yang bermanfaat bersama dengan keterlibatan CSR untuk penyelesaian konflik di antara para stake holders yang berbeda. Jika metode corporate governance dan pengendalian yang berbeda membangun keterlibatan CSR sebagai upaya untuk mengurangi kemungkinan resolusi konflik di antara para stake holders, maka diharapkan akan ada hubungan afirmatif antara praktik CG dan CSR .

Bersamaan dengan meningkatnya kepedulian terhadap pengungkapan CSR, Corporate governance (CG) juga telah berkembang 
untuk mengakomodasi hubungan baru yang sebelumnya tidak pernah dianggap diperlukan, yaitu hubungan bisnis-lingkungan dan bisnismasyarakat.Misalnya, Claessens $(2003,7)$ menyatakan, "Dalam arti luasnya, CG berkepentingan dengan keseimbangan di antara keduanya tujuan ekonomi dan sosial dan antara tujuan individu dan komunal ".Selanjutnya, CG dikembangkan dengan memasukkan etika, akuntabilitas, pengungkapan, dan pelaporan.

Dengan demikian, mekanisme CG yang berbeda, seperti dewan direksi, komite audit, dan auditor bertanggung jawab untuk memantau dan mengendalikan keputusan manajer dan kegiatan perusahaan yang mempengaruhi semua pemangku kepentingan termasuk masyarakat.Ini mungkin mengungkapkan korelasi antara efektivitas sistem CG dan kualitas pengungkapan CSR.Sistem CG yang efektif mungkin berkaitan dengan pengungkapan dan transparansi secara umum, dan dengan pengungkapan materikegiatan yang mempengaruhi masyarakat dan lingkungan pada khususnya. Secara empiris, Said et al. (2009) menemukan korelasi positif yang signifikan antara kepemilikan pemerintah dan komite audit dengan Pengungkapan CSR. Khan (2010) menemukankorelasi signifikan positif antara ukuran dewan, struktur kepemilikan, dan noneksekutif independen direksi dengan pengungkapan CSR. Temuan ini mendukung hipotesis potensi korelasi positif antara CG dan pengungkapan CSR.

Di Indonesia sendiri, pemerintah telah mengeluarkan UndangUndang mengenai pelaporan CSR sebagaimana dimuat dalam Undangundang No. 40 tahun 2007 tentang Perseroan Terbatas.Didalam undangundang tersebut pada pasal 66 ayat 2c menyatakan bahwa perusahaan harus menyampaikan laporan tahunan yang memuat laporan pelaksanaan tanggung jawab sosial dan lingkungan.Lebih lanjut dijelaskan pada Peraturan Pemerintah No. 47 Tahun 2012 tentang tanggung jawab sosial dan lingkungan perseroan terbatas.Pada pasal 6 PP No.47 Tahun 2012 menjelaskan bahwa pelaksanaan tanggung jawab sosial dan lingkungan wajib dimuat dalam laporan tahunan Perseroan dan dapat dipertanggungjawabkan.

Walaupun pemerintah telah mengeluarkan peraturan bagi perusahaan perseroan untuk wajib mengungkapkan laporan CSR di dalam laporan tahunan, masih belum ada standar yang mengatur tentang teknis pengungkapan CSR. Perusahaan-perusahaan hanya diwajibkan untuk melakukan praktik CSR dan memberikan pelaporan pertanggung jawaban atas praktik CSR yang telah dilakukan, sedangkan tata cara untuk 
pelaporan tanggung jawab social didalam laporan tahunan perusahaan belum diatur. Hal ini menyebabkan perbedaan pengungkapan yang dilakukan oleh perusahaan di Indonesia.

Penelitian ini merupakan replikasi dari penelitian Sadia Majeed, Tariq Aziz and Saba Saleem (2015) yang berjudul The Effect of Corporate governance Elements on Corporate social responsibility (CSR) Disclosure: An Empirical Evidencefrom Listed Companies at KSE Pakistan. Mereka menemukan pengaruh positif Ukuran dewan komisaris, Kepemilikan Institusional, dan Ukuran perusahaan terhadap pengungkapan CSR.

Dari uraian diatas, maka penulis tertarik untuk meneliti tentang Pengaruh Karakteristik Good Corporate governance terhadap Pengungkapan Corporate social responsibility dengan rumusan masalah sebagai berikut; Bagaimana Pengaruh Good Corporate governance Terhadap Pengungkapan Corporate social responsibility

\section{TELAAH TEORI}

\section{Agency Theory}

Menurut Sutedi (2012:14-15) untuk memahami Good Corporate governance (GCG), jalan yang paling dekat adalah dengan memahami teori agensi (Agency Theory). Teori ini memberikan wawasan analisis untuk bisa mengkaji dampak dari hubungan agents dengan principal, atau principal dengan principal. Teori agensi menjawab dengan memberikan gambaran hal-hal apa saja yang berpeluang akan terjadi baik antara pengelola (agent) dengan pemegang saham (principal) maupun antara pemegang saham (principal) dengan pemberi pinjaman (principal). Pengertian principal dalam agency theory adalah pihak-pihak yang menyerahkan sebagian atau seluruh wealth nya untuk di kembangkan oleh pihak lain.

Menurut Jensen dan Meckling (1976) teori agency adalah sebagai suatu versi dari game theory yang membuat suatu model kontraktual antara dua atau lebih oleh orang (pihak), dimana salah satu pihak disebut agen dan pihak lain di sebut principal. Dengan adanya perkembangan perusahaan atau entitas bisnis yang semakin besar maka sering terjadi konflik antara principal, dalam hal ini adalah para pemegang saham (investor) dan pihak agen yang di wakili oleh manajemen (direksi). Asumsi bahwa manajemen yang terlibat dalam perusahaan akan selalu memaksimumkan nilai perusahaan ternyata tidak selalu terpenuhi. Manajemen memiliki kepentingan pribadi yang bertentangan dengan 
kepentingan pemilik perusahaan sehingga muncul masalah yang di sebut dengan masalah agensi (problem agency).Untuk mengurangi adanya masalah agensi ini di perlukan adanya pihak independen yang dapat menjadi pihak penengah menangani konflik tersebut.

Tujuan dari di pisahkannya pengelolaan dari kepemilikan perusahaan yaitu agar pemilik perusahaan memperoleh keuntungan yang semaksimal mungkin dengan biaya yang seefisien mungkin dengan di kelolanya perusahaan oleh tenaga-tenaga profesional.Mereka, para tenaga profesional bertugas untuk kepentingan perusahaan dan memiliki keleluasan dalam menjalankan manajemen perusahaan sehingga dalam hal ini para profesional tersebut berperan sebagai agents-nya pemegang saham.Semakin besar perusahaan yang di kelola memperoleh laba semakin besar pula keuntungan yang di dapatkan agents.Sementara pemilik perusahaan (pemegang saham) hanya bertugas mengawasi dan memonitor jalannya perusahaan yang di kelola oleh manajemen serta mengembangkan sistem insentif bagi pengelola manajemen untuk memastikan bahwa mereka bekerja demi kepentingan perusahaan.

\section{Stakeholder theory}

Premis dasar dari teori stakeholder adalah bahwa semakin kuat hubungan korporasi, maka akan semakin baik bisnis korporasi. Sebaliknya, semakin buruk hubungan korporasi maka akan semakin sulit. Hubungan yang kuat dengan para pemangku kepentingan adalah berdasarkan kepercayaan, rasa hormat, dan kerjasama.Teori stakeholder adalah sebuah konsep manajemen strategis, tujuannya adalah untuk membantu korporasi memperkuat hubungan dengan kelompok-kelompok eksternal dan mengembangkan keunggulan kompetitif (Totok Mardikanto, 2011).

Teori stakeholder mengatakan bahwa perusahaan bukanlah entitas yang hanya beroperasi untuk kepentingannya sendiri namun harus memberikan manfaat bagi stakeholdernya.Dengan demikian, keberadaan suatu perusahaan sangat dipengaruhi oleh dukungan yang diberikan oleh stakeholder kepada perusahaan tersebut.Gray, Kouhy dan Adams mengatakan bahwa kelangsungan hidup perusahaan tergantung pada dukungan stakeholders sehingga aktivitas perusahaan adalah untuk mencari dukungan tersebut. Semakin powerful stakeholder, maka semakin besar usaha perusahaan untuk beradaptasi. Pengungkapan tanggung jawab sosial dianggap sebagai bagian dari dialog antara perusahaan dengan stakeholdernya. 


\section{Good Corporate governance}

Menurut Sutedi (2012:1) Good Corporate governance (GCG) dapat di defenisikan sebagai suatu proses dan struktur yang di gunakan oleh organ perusahaan (pemegang saham/pemilik modal, komisaris atau dengan pengawas dan direksi) untuk meningkatkan keberhasilan usaha dan akuntabilitas perusahaan guna mewujudkan nilai pemegang saham dalam jangka panjang dengan tetap memperhatikan kepentingan stakeholder lainnya, berlandaskan peraturan perundang-undangan dan nilai-nilai estetika.

Corporate governance adalah seperangkat peraturan yang mengatur hubungan antara pemegang saham, pengurus (pengelola) perusahaan, pihak kreditor, pemerintah, karyawan, serta para pemangku kepentingan internal dan eksternal lainnya yang berkaitan dengan hak-hak dan kewajiban mereka atau dengan kata lain suatu sistem yang mengendalikan perusahaan. istilahCorporate governance ini muncul karna adanya agency theory, dimana kepengurusan suatu perusahaan terpisah dari kepemilikan.

Sistem yang mengatur keseimbangan dalam pengelolaan perusahaan perlu di tuangkan dalam bentuk-bentuk prinsip-prinsip yang harus di patuhi untuk menuju rata-rata kelola perusahaaan yang baik. Berdasarkan surat keputusan Mentri BUMN No: KEP-117/M-MBU/2002 Prinsip-prinsip Good Corporate governanceyaitu :

1. Transparancy( Keterbukaan Informasi ) adalah keterbukaan dalam melaksanakan proses pengambilan keputusan dan pengungkapan informasi material yang relevan mengenai perusahaan.

2. Independence( Kemandirian) adalah suatu keadaan dimana perusahaan di kelola secara profesional tanpa konflik kepentingan dan pengaruh atau tekanan dari pihak manapun yang tidak sesuai dengan peraturan perundang-undangan yang berlaku dan prinsipprinsip korporasi yang sehat.

3. Accountability (Akuntabilitas) adalah kejelasan fungsi, pelaaksanaan, serta pertanggungjawaban manajemen perusahaan terlaksana secara efektif dan ekonomis

4. Responsibility ( Pertanggungjawaban), pertanggungjawaban perusahaan adalah kesesuaian pengelolaan perusahaan terhadap peraturan perundang-undangan yang berlaku dan prinsip-prinsip korporasi yang sehat. 
5. Fairness (Kewajaran), keadilan dan kesetaraan dalam hak-hak pemangku yang timbul sebagai akibat dari perjanjian dan peraturan perundang-undangan yang berlaku.

\section{Pengungkapan Tanggung Jawab Sosial Perusahaan}

Pengungkapan tanggung jawab sosial perusahaan yang sering juga disebutsebagai social disclosure, corporate social reporting, social accounting (Mathews,1995) atau corporate social responsibility(Hackston dan Milne, 1996) merupakan prosespengkomunikasian dampak sosial dan lingkungan dari kegiatan ekonomi organisasiterhadap kelompok khusus yang berkepentingan dan terhadap masyarakat secarakeseluruhan. Hal tersebut memperluas tanggung jawab organisasi (khususnyaperusahaan), di luar peran tradisionalnya untuk menyediakan laporan keuangan kepadapemilik modal, khususnya pemegang saham.Perluasan tersebut dibuat dengan asumsibahwa perusahaan mempunyai tanggung jawab yang lebih luas dibanding hanya mencarilaba untuk pemegang saham (Grayet. al., 1987).

Menurut Grayet. al., (1995) ada dua pendekatan yang secara signifikan berbedadalam melakukan penelitian tentang pengungkapan tanggung jawab sosial perusahaan.Pertama, pengungkapan tanggung jawab sosial perusahaan mungkin diperlakukansebagai suatu suplemen dari aktivitas akuntansi konvensional. Pendekatan ini secaraumum akan menganggap masyarakat keuangan sebagai pemakai utama pengungkapantanggung jawab sosial perusahaan dan cenderung membatasi persepsi tentang tanggungjawab sosial yang dilaporkan.

Pendekatan alternatif kedua dengan meletakkan pengungkapan tanggung jawabsosial perusahaan pada suatu pengujian peran informasi dalam hubungan masyarakat danorganisasi.Pandangan yang lebih luas ini telah menjadi sumber utama kemajuan dalampemahaman tentang pengungkapan tanggung jawab sosial perusahaan dan sekaligusmerupakan sumber kritik yang utama terhadap pengungkapan tanggung jawab social perusahaan.

\section{Karakteristik Corporate governance dan Pengungkapan CSR Ukuran Dewan Komisaris}

Dewan komisaris merupakan salah satu fungsi kontrol yang terdapat dalam suatu perusahaan.fungsi kontrol yang dilakukan oleh dewan komisaris merupakan salah satu bentuk praktis dan theory agensi. Dalam suatu perusahaan dewan komisaris mewakili mekanisme internal utama 
untuk melaksanakan fungsi pengawasan dari principal dan mengontrol perilaku opportunis manajemen.Dewan komisaris menjembatani kepentingan principal dan manajer dalam perusahaan.

Berkaitan dengan ukuran dewan komisaris, Coller dan Gregory (1999)menyatakan bahwa semakin besar jumlah anggota dewan komisaris, maka akan semakinmudah untuk mengendalikan CEO dan monitoring yang dilakukan akan semakin efektif.Dikaitkan dengan pengungkapan tanggung jawab sosial, maka tekanan terhadapmanajemen juga akan semakin besar untuk mengungkapkannya. Oleh karena itu, sejalandengan pendapat Coller dan Gregory (1999), Beasley (2000) dan Arifin (2002), hipotesisberikut ini dikemukakan:

$\mathrm{H}_{1}$ : Ukuran dewan komisaris berpengaruh positif terhadap pengungkapan CSR

\section{Direktur Independen}

Dewan direksi yaitu dewan yang dipilih oleh pemegang saham, bertugas mengawasi pekerjaan yang di lakukan manajemen dalam mengelola perusahaan, dengan tujuan kepentingan para pemegang saham.Dewan direksi pada perusahaan bertindak sebagai agen dalam perusahaan.direksi menjalankan kegiatan operasional perusahaan dan juga berdasarkan atas kewenangan yang di terima dari pemilik perusahaandan ini juga bertanggungjawab langsung terhadap jalannya kegiatan operasional perusahaan .

Dalam perspektif CG, direktur independen cenderung melaksanakan mengamati fungsi untuk memastikan bahwa kepentingan pemegang saham dipertimbangkan sementara membuat keputusan dewan.Namun, hubungan antara direktur independen dan pelaporan CSR tidak jelas.Cheng,dan Courtenay (2006) dan Donnelly, R.; Mulcany, M (2008) menemukan pengaruh positif antara keduanya direktur independen dan pelaporan CSR. Sementara Eng, L.L.dan Mak, Y.T. (2003) serta Barako, D.G.dan ; Hancock, P.(2006)mendapatkan hasil yang kontradiktif.

$\mathrm{H}_{2}$ : Proporsi Direktur independen berpengaruh positif terhadap pengungkapan CSR.

\section{Direktur Perempuan}

Dari literatur $\mathrm{CG}$, telah terbukti bahwa keragaman dewan telah berubah menjadi komponen penting dari pengaturan CG dalam beberapa tahun terakhir.Penelitian terdahulu menunjukkan bahwa keragaman dewan dikaitkan dengan pelaporan sosial perusahaan dan menghasilkan intensitas 
tinggi kinerja social.Carter et al.(2003) mendukung keragaman dewan akan meningkatkan independensi dewan.Mereka selanjutnya mengekspos bukti eksperimental hubungan positif yang cukup besar antara keragaman dewan dalam hal persentase perempuan dalam dewan direktur dan nilai-nilai perusahaan.

$\mathrm{H}_{3}$ : Proporsi direktur Perempuanberpengaruh positif terhadap pengungkapan CSR

\section{Konsentrasi Kepemilikan}

Studi sebelumnya dari Said, Yuserrie, dan Hasnah (2009) melaporkan hasil yang cukup positif hubungan OC dan pengungkapan CSR di perusahaan publik Malaysia. Pekerjaan khusus ini memanfaatkan persentase saham yang dimiliki oleh lima pemegang saham utama untuk menghitung dan menempatkannya konsentrasi kepemilikan dapat berdampak pada pelaporan CSR

pengungkapan CSR

$\mathrm{H}_{4}$ : Konsentrasi kepemilikan berpengaruh positif terhadap

\section{Komisaris Independen}

Ratnasari dan Prastiwi (2010) berpendapat bahwa keberadaan komisaris independen diharapkan dapat bersikap netral terhadap segala kebijakan yang dibuat oleh direksi.Keberadaan dewan komisaris independen tidak terpengaruh oleh manajemen, oleh karena itu mereka cenderung mendorong perusahaan untuk mengungkapkan informasi yang lebih luas kepada para stakeholder-nya.Dengan demikian, semakin besar proporsi dewan komisaris dalam perusahaan dapat mendorong pengungkapan informasi sosial dan lingkungan yang lebih luas.

$\mathrm{H}_{5}=$ Komisaris Independen berpengaruh positif terhadap pengungkapan CSR 


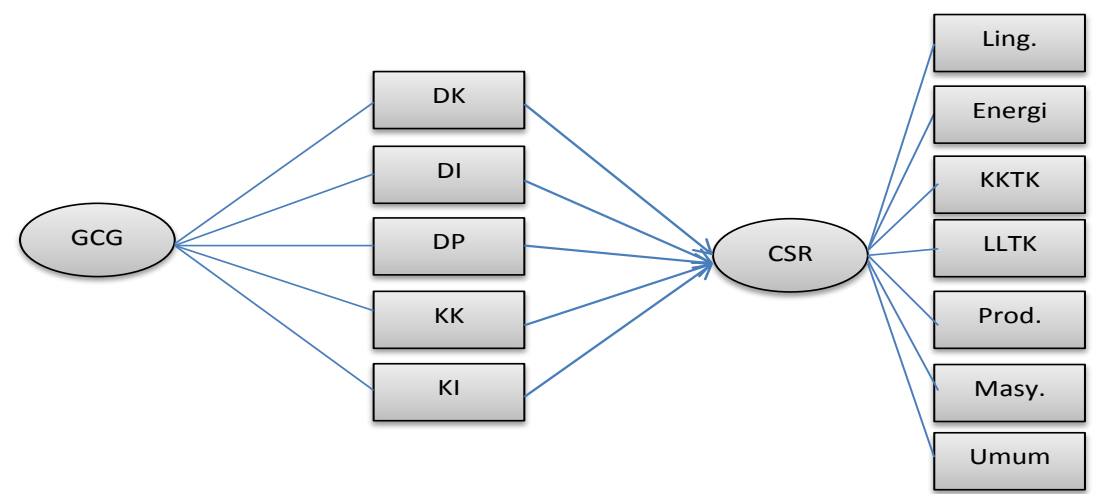

\section{METODE PENELITIAN}

\section{Populasi dan Sampel}

Populasi dalam penelitian ini adalah semua perusahaan yang tercatat (go-public)di Bursa Efek Indonesia (BEI) Penggunaan perusahaan yang tercatat di BEI sebagai populasi karenaperusahaan tersebut mempunyai kewajiban untuk menyampaikan laporan tahunan kepadapihak luar perusahaan, sehingga memungkinkan data laporan tahunan tersebut diperolehdalam penelitian ini.

Dari perusahaan yang tercatat di BEI sebanyak 41 perusahaan dalam sector pertambangan digunakan menjadisampel karena sector ini secara eksplisit dinyatakan sebagai perusahaan yang menjalankan usahanya dibidang dan/atau berkaitan dengan sumber daya alam (pasal 74 UU No: 40 Thn 2007 tentang Perseroan terbatas).

\section{Operasionalisasi Variabel}

\section{Variabel dependen}

Checklist dilakukan dengan melihat pengungkapan tanggung jawab social perusahaan dalam tujuh kategori yaitu: lingkungan, energi, kesehatan dan keselamatantenaga kerja, lain-lain tenaga kerja, produk, keterlibatan masyarakat, dan umum. Kategoriini diadopsi dari penelitian Sembiring (2006). Tujuh puluh delapan item CSR yang diharapkan diungkapkan sector pertambangan dapat dilihat pada lampiran 1 . 
Variabel Independen

Ukuran Dewan Komisaris : Ukuran dewan komisaris yang digunakan dalam penelitianini konsisten dengan Beasley (2000) yaitu jumlah anggota dewan komisaris.

Direktur Independen $\quad$ : Persentase direktur Independen

Direktur Perempuan : persentase direktur Perempuan dalam dewan direksi

Konsentrasi Kepemilikan : Persentase saham yang dimiliki 3 pemegang saham terbesar

Komisaris Independen $\quad$ : Persentase anggota dewan komisaris Independen

\section{Model Penelitian}

Adapun persamaan untuk menguji hipotesis secara keseluruhan dalam penelitianini adalah sebagai berikut:

\section{CSRD $=\beta 0+\beta 1 D K+\beta 2 D I+\beta 3 D P+\beta 4 K K+\beta 5 K I+e$}

Dimana:

CSRD $=$ Indeks pengungkapan tanggung jawab sosial

DK = Dewan Komisaris

DI $=$ Direktur Independen

$\mathrm{DP}=$ Direktur Perempuan

KK $=$ Konsentrasi Kepemilikan

$\mathrm{KI}=$ Komisaris Independen

$\beta 0=$ konstanta

$\mathrm{e}=$ Error

$\beta 1, \ldots, \beta 5=$ Koefisien regresi

\section{Teknik Pengumpulan Data}

Teknik pengumpulan data yang digunakan dalam penelitian ini adalah teknik dokumentasi yang diperoleh dari www.bei.co.id. Data yang digunakan dalam penelitian ini adalah data sekunder, yakni adalah data dalam Laporan Tahunan berupa pengungkapan tanggung jawab sosial, Dewan Komisaris, Direktur Independen, Direktur Perempuan, Konsentrasi Kepemilikan, dan Komisaris Independen.

\section{Uji kualitas Data}

Sebelum melakukan analisis regresi berganda terlebih dahulu dilakukan pengujian kualitas data dengan melakukan Uji asumsi klasik 
yakni Uji Normalitas Data, Uji Multikolonieritas, Uji Heteroskedastisitas dan Uji Autokorelasi.

\section{Pengujian Hipotesis}

\section{Pengujian Hipotesis Secara Simultan (Uji-F)}

Uji-F dimaksudkan untuk melihat kemampuan menyeluruh dari variabel bebas dapat atau mampu menjelaskan tingkah laku atau keragaman variabel terikat. Uji ini juga dimaksudkan untuk mengetahui apakah semua variabel bebas memiliki koefisien regresi sama dengan nol. Untuk menguji hipotesis yang diajukan, digunakan rumusan hipotesis sebagai berikut:

1. H0 : $\beta 1, \beta 2, \beta 3, \beta 4, \beta 5=0$ (Dewan Komisaris, Direktur Independen, Direktur Perempuan, Konsentrasi Kepemilikan, dan Kepemilikan Institusional secara bersama sama tidak berpengaruh terhadap Pengungkapan CSR)

2. H1 : $\beta 1, \beta 2, \beta 3, \beta 4, \beta 5 \neq 0$ (Dewan Komisaris, Direktur Independen, Direktur Perempuan, Konsentrasi Kepemilikan, dan Kepemilikan Institusional secara bersama sama berpengaruh terhadap Pengungkapan CSR)

3.

Kriteria pengujian:

1. Jika tingkat signifikansi $>0,05$ pada $\alpha=5 \%$ maka $\mathrm{H}_{0}$ diterima dan $\mathrm{H}_{1}$ ditolak.

2. Jika tingkat signifikansi $<0,05$ pada $\alpha=5 \%$ maka $\mathrm{H}_{0}$ ditolak dan $\mathrm{H}_{1}$ diterima.

\section{Pengujian Hipotesis Secara Parisal (Uji-t)}

Menurut Suharyadi dan Purwanto (2011:228), uji signifikansi parsial digunakan untuk menguji apakah suatu variabel bebas berpengaruh atau tidak terhadap variabel terikat. Untuk menguji hipotesis yang diajukan, digunakan rumusan hipotesis sebagai berikut:

$\mathrm{H}_{0}: \beta 1, \beta 2, \beta 3, \beta 4, \beta 5 \leq 0$ (Dewan Komisaris, Direktur Independen, Direktur Perempuan, Konsentrasi Kepemilikan, dan Kepemilikan Institusional secara parsial tidak berpengaruh positif terhadap Pengungkapan CSR)

$\mathrm{H}_{1}: \beta 1, \beta 2, \beta 3, \beta 4, \beta 5>0$ (Dewan Komisaris, Direktur Independen, Direktur Perempuan, Konsentrasi Kepemilikan, dan Kepemilikan Institusional secara secara parsial berpengaruh positif terhadap Pengungkapan CSR) 
Kriteria pengujian t:

1. Jika tingkat signifikansi $>0,05$ pada $\alpha=5 \%$ maka $\mathrm{H}_{0}$ diterima dan $\mathrm{H}_{1}$ ditolak.

2. Jika tingkat signifikansi $<0,05$ pada $\alpha=5 \%$ maka $\mathrm{H}_{0}$ ditolak dan $\mathrm{H}_{1}$ diterima.

\section{HASIL DAN PEMBAHASAN}

\section{Gambaran Umum Sampel Penelitian}

Data pada penelitian ini merupakan data sekunder yang diperoleh dari Bursa Efek Indonesia melalui situs www.idx.co.id. Data yang dibutuhkan dalam penelitian ini sesuai dengan variabel penelitian antara lain: tanggung jawab sosial perusahaan, jumlah anggota dewan komisaris, proporsi direktur independen, proporsi direktur perempuan, konsentrasi kpemilikan dan proporsi komisaris independen. Semua data ini diperoleh dari laporan tahunan perusahaan.

Populasi dalam penelitian ini adalah semua perusahaan yang tercatat di Bursa Efek Indonesia pada tahun 2018. Pengambilan sampel dilakukan dengan teknik purposive sampling yakni perusahaan sektor pertambangan. Pemilihan sektor pertambangan sebagai sampel adalah karena sektor pertambangan berdasarkan Undang-Undang No. 40 Tahun 2007 tentang Perseroan Terbataspasal 74 menyatakan bawwa tanggung jawab sosial wajib untuk perseroan yang menjalankan kegiatan usahanyadi bidang dan atau berkaitan dengan sumber daya alam. Jumlah perusahaan sektor pertambangan yang tercatat di Bursa Efek Indonesia pada tahun 2018 adalah 48 perusahaan. Sebanyak 7 perusahaah dikeluarkan dari sampel karena datanya tidak tersedia di www.idx.co.id pada tahun 2018, sehingga 41 perusahaan kemudian digunakan sebagai sampel.

\section{Uji Hipotesis}

\section{Hasil Uji Koefisien Determinasi (R Square)}

\section{Model Summary}

\begin{tabular}{|l|l|r|r|r|r|}
\hline $\begin{array}{l}\text { Mode } \\
\perp\end{array}$ & $\mathrm{R}$ & $\mathrm{R}$ Square & $\begin{array}{c}\text { Adjusted R } \\
\text { Square }\end{array}$ & $\begin{array}{c}\text { Std. Error of } \\
\text { the Estimate }\end{array}$ & $\begin{array}{c}\text { Durbin- } \\
\text { Watson }\end{array}$ \\
\hline 1 & $.580^{\mathrm{a}}$ & .336 & .241 & 16.72398 & 1.497 \\
\hline
\end{tabular}

a. Predictors: (Constant), $\mathrm{KI}, \mathrm{Dl}, \mathrm{KK}, \mathrm{DK}, \mathrm{DP}$

b. Dependent Variable: CSR

Dari tabel di atas terlihat nilai koefisien determinasi yang ditunjukkan oleh $r$ square sebesar 0,336 . Nilai ini mengindikasikan bahwa 
kontribusi variabel ukuran dewan komisaris, proporsi direktur independen, proporsi direktur perempuan, konsentrasi kpemilikan dan proporsi komisaris independen terhadap pengungkapan tanggung jawab sosial perusahaan sebesar $33,60 \%$, sedangkan sebesar $66,40 \%$ ditentukan oleh variabel lain.

\section{Uji F(simultan)}

ANOVA ${ }^{b}$

\begin{tabular}{|ll|r|r|r|r|r|}
\hline Model & & \multicolumn{1}{c|}{$\begin{array}{c}\text { Sum of } \\
\text { Squares }\end{array}$} & df & Mean Square & F & Sig. \\
\hline 1 & Regression & 4954.865 & 5 & 990.973 & 3.543 & $.011 z$ \\
& Residual & 9789.200 & 35 & 279.691 & & \\
& Total & 14744.065 & 40 & & & \\
\hline
\end{tabular}

a. Predictors: (Constant), $\mathrm{KI}, \mathrm{DI}, \mathrm{KK}, \mathrm{DK}, \mathrm{DP}$

b. Dependent Variable: CSR

Dari tabel di atas terlihat bahwa nilai signifikansi sebesar 0,011 lebih kecil dari 0,05 . Hal ini mengindikasikan bahwa secara bersama sama variabel ukuran dewan komisaris, proporsi direktur independen, proporsi direktur perempuan, konsentrasi kepemilikan dan proporsi komisaris independen berpengaruh signifikan terhadap pengungkapan tanggung jawab sosial perusahaan pada tingkat signifikansi $5 \%$.

\section{Uji t (Parsial)}

\begin{tabular}{|c|c|c|c|c|c|c|}
\hline \multirow[b]{2}{*}{ Mad } & & \multicolumn{2}{|c|}{ Unstandardized Coefficients } & \multirow{2}{*}{$\begin{array}{c}\text { Standardized } \\
\text { Coefficients }\end{array}$} & \multirow[b]{2}{*}{$t$} & \multirow[b]{2}{*}{ Sig. } \\
\hline & & $\mathrm{B}$ & Std. Error & & & \\
\hline \multirow[t]{6}{*}{1} & (Constant) & 7.701 & 21.307 & & .361 & .720 \\
\hline & DK & 6.727 & 1.781 & .571 & 3.776 & .001 \\
\hline & $\mathrm{DI}$ & .336 & .177 & .284 & 1.896 & .066 \\
\hline & DP & .127 & .194 & .102 & .656 & .516 \\
\hline & KK & .165 & .159 & .153 & 1.034 & .308 \\
\hline & $\mathrm{KI}$ & -.340 & .310 & -.170 & -1.097 & 280 \\
\hline
\end{tabular}

a. Dependent Variable: CSR

Berdasarkan tabel output regresi berganda di atas maka dapat dirumuskan persamaan regresi sebagai berikut:

CSRD $=7,701+6,727 \mathrm{DK}+0,336 \mathrm{DI}+0,127 \mathrm{DP}+0,165 \mathrm{KK}-0,340 \mathrm{KI}$

\section{Pengujian Hipotesis 1}

Pada tingkat $\alpha=5 \%$.Ukuran Dewan Komisaris berpengaruh positif signifikan terhadap pengungkapan tanggung jawab sosial perusahaan karena nilai signifikansi 0,001 lebih kecil dari 0,05 dan nilai $\beta(+)$ sebesar 
6,727. Dengan demikian hipotesis 1 yang menyatakan ukuran dewan komisaris berpengaruh positif terhadap pengungkapan tanggung jawab sosial perusahaan, tidak dapat ditolak pada tingkat $\alpha=5 \%$.

\section{Pengujian Hipotesis 2}

Pada tingkat $\alpha=5 \%$ Proporsi Direktur Independen berpengaruh positif tidak signikan terhadap pengungkapan tanggung jawab sosial perusahaan karena nilai signifikansi 0,066 lebih besar dari 0,05 dan nilai $\beta$ (+) sebesar 0,336. Dengan demikian hipotesis 2 yang menyatakan Proporsi Direktur Independen berpengaruh positif terhadap pengungkapan tanggung jawab sosial perusahaan, dapat ditolak pada tingkat $\alpha=5 \%$.

\section{Pengujian Hipotesis 3}

Pada tingkat $\alpha=5 \%$ proporsi direktur perempuan berpengaruh positif tidak signikan terhadap pengungkapan tanggung jawab sosial perusahaan karena nilai signifikansi 0,516 lebih besar dari 0,05 dan nilai $\beta$ (+) sebesar 0,127. Dengan demikian hipotesis 3 yang menyatakan ukuran dewan komisaris berpengaruh positif terhadap pengungkapan tanggung jawab sosial perusahaan, dapat ditolak pada tingkat $\alpha=5 \%$.

\section{Pengujian Hipotesis 4}

Pada tingkat $\alpha=5 \%$.konsentrasi kepemilikan berpengaruh positif tidak signifikan terhadap pengungkapan tanggung jawab sosial perusahaan karena nilai signifikansi 0,308 lebih besar dari 0,05 dan nilai $\beta(+)$ sebesar 0,165 . Dengan demikian hipotesis 4 yang menyatakan konsentrasi kepemilikan berpengaruh positif terhadap pengungkapan tanggung jawab sosial perusahaan, dapat ditolak pada tingkat $\alpha=5 \%$.

\section{Pengujian Hipotesis 5}

Pada tingkat $\alpha=5 \%$ proporsi komisaris independen berpengaruh negatiftidak signifikan terhadap pengungkapan tanggung jawab sosial perusahaan karena nilai signifikansi 0,280 lebih besar dari 0,05 dan nilai $\beta$ (-) sebesar 0,340. Dengan demikian hipotesis 1 yang menyatakan proporsi komisaris independen berpengaruh positif terhadap pengungkapan tanggung jawab sosial perusahaan, dapat ditolak pada tingkat $\alpha=5 \%$.

\section{Pembahasan}

Dalam pengujian secara simultan, tingkat pengaruh variabel independen (DK, DI, DP, KK, KI) terhadap pengungkapan tanggung jawab 
sosial (CSR) yang ditemukan cukup rendah yaitu sebesar $33,60 \% \quad(R$ square $=0,336$ ). Hal ini berarti bahwa secara simultan, ukuran dewan komisaris, direktur Independen, direktur perempuan, konsentrasi kepemilikan dan komisaris independen mampu mempengaruhi tingkat pengungkapan tanggung jawab sosial sebesar 33,60\%. Sisanya sebesar $66,40 \%$ dipengaruhi oleh variabel lain diluar variabel yang digunakan.

Tingkat $R$ square yang rendah ini menunjukkan perlunya dilakukan penelitian lanjutan dengan menambahkan variabel lain sebagai penduga pengungkapan tanggung jawab sosial perusahaan. Walaupun demikian, dilihat dari signifikansinya, secara simultan variabel yang digunakan berpengaruh secara signifikan dengan nilai $\mathrm{F}$ sebesar 3,543.

Dalam pengujian secara parsial hanya variabel ukuran dewan komisaris yang berpengaruh signifikan terhadap pengungkapan tanggung jawab sosial perusahaan.sedangkandirektur Independen, direktur perempuan, konsentrasi kepemilikan dan komisaris independen mempunyai pengaruh yang tidak signifikan. Pembahasan terhadap masing-masing variabel dalam pengujian secara parsial dibuat secara khusus pada subbagian berikut ini di bawah ini.

\section{Pengaruh Dewan Komisaris terhadap Pengungkapan Tanggung Jawab Sosial}

Berdasarkan teori agensi, dewan komisaris dianggap sebagai mekanisme pengendalian intern tertinggi, yang bertanggung jawab untuk memonitor tindakan manajemen puncak.Dikaitkan dengan pengungkapan informasi oleh perusahaan, kebanyakan penelitian menunjukkan adanya hubungan positif antara berbagai karakteristik dewan komisaris dengan tingkat pengungkapan informasi oleh perusahaan.

Dalam penelitian ini ukuran dewan komisaris yang diproksi dengan jumlah anggota dewan komisaris, menunjukkan pengaruh yang positif signifikan terhadap pengungkapan tanggung jawab sosial perusahaan dengan nilai $\mathrm{t}=3,776$ dan $p=0,001(p<0,05)$. Hal ini berarti bahwa semakin banyak jumlah anggota dewan komisaris dalam suatu perusahaan, maka pengungkapan tanggung jawab sosial yang dibuat perusahaan akan semakin luas.

Hasil penelitian ini berhasil mendukung teori agensi dan sesuai dengan pendapat Coller dan Gregory (1999) yang menyatakan bahwa semakin besar jumlah anggota dewan komisaris, maka akan semakin mudah untuk mengendalikan CEO dan monitoring yang dilakukan akan semakin efektif. Dikaitkan dengan pengungkapan tanggung jawab sosial, 
maka tekanan terhadap manajemen juga akan semakin besar untuk mengungkapkannya.

Hasil ini juga berhasil mendukung hasil penelitian Sembiring (2006) yang yang menemukan bahwa dewan komisaris berpengaruh positif signifikan terhadap pengungkapan tanggung jawab sosial perusahaan manufaktur di Indonesia.

\section{Pengaruh Direktur Independen terhadap Pengungkapan Tanggung Jawab Sosial}

Dewan direksi yaitu dewan yang dipilih oleh pemegang saham, bertugas mengawasi pekerjaan yang di lakukan manajemen dalam mengelola perusahaan, dengan tujuan kepentingan para pemegang saham.Dalam perspektif teori agensi dewan direksi bertindak sebagai agen dalam perusahaan yang mengetahui lebih banyak informasi operasional perusahaan dibandingkan dengan pemilik (principal).

Dalam perspektif $\mathrm{CG}$, direktur independen cenderung melaksanakan fungsi untuk memastikan bahwa kepentingan pemegang saham dipertimbangkan dalam membuat keputusan dewan.Namun, hubungan antara direktur independen dan pelaporan CSR tidak jelas.Cheng,dan Courtenay (2006) dan Donnelly, R.; Mulcany, M (2008) menemukan pengaruh positif. Sementara Eng, L.L.dan Mak, Y.T. (2003) serta Barako, D.G.dan ; Hancock, P.(2006) mendapatkan hasil yang kontradiktif.

Dalam penelitian ini Direktur independen yang diproksi dengan proporsi direktur independen dalam dewan direksi, menunjukkan pengaruh yang positif tidak signifikan terhadap pengungkapan tanggung jawab sosial perusahaan dengan nilai $\mathrm{t}=1,896$ dan $p=0,066(p>0,05)$. Pengaruh positif ini dapat diartikan bahwa semakin tinggi proporsi direktur independenmaka pengungkapan tanggung jawab sosial yang dibuat perusahaan akan semakin luas.

Hasil penelitian ini sejalan dengan temuan Cheng,dan Courtenay (2006) dan Donnelly, R.; Mulcany, M (2008) yang menemukan pengaruh positif direktur independen terhadap pengungkapan tanggung jawab sosial perusahaan.

\section{Pengaruh Direktur Perempuan terhadap Pengungkapan Tanggung Jawab Sosial}

Carter et al. (20030 menyatakan bahwa keragaman anggota dewan direksi akan meningkatkan independensi dewan. Mereka mengekspos bukti 
eksperimental hubungan positif yang cukup besar antara keragaman dewan direksi dalam hal persentase perempuan dalam dewan direktur dan nilainilai perusahaan.

Dalam penelitian ini direktur perempuan yang diproksi dengan proporsi direktur perempuan dalam dewan direksi, menunjukkan pengaruh yang positif tidak signifikan terhadap pengungkapan tanggung jawab sosial perusahaan dengan nilai $\mathrm{t}=0,656$ dan $p=0,516(p>0,05)$. Pengaruh positif ini dapat diartikan bahwa semakin tinggi proporsi direktur perempuan dalam dewan direksimaka pengungkapan tanggung jawab sosial yang dibuat perusahaan akan semakin luas.

\section{Pengaruh Konsentrasi Kepemilikan terhadap Pengungkapan Tanggung Jawab Sosial}

Penelitian dari Said, Yuserrie, dan Hasnah (2009) serta penelitian Sadia Majeed et. al.menemukanpengaruh positif konsentrasi kepemilikan terhadap pengungkapan tanggung jawab sosial perusahaan. Hal uang sama ditemukan dalam penelitian ini dimana konsentrasi kepemilikan yang diproksi dengan persentase saham yang dimiliki oleh tiga pemegang saham terbesar ditemkan berpengaruh positif tidak signifikan terhadap pengungkapan tanggung jawab sosial perusahaan dengan nilai $\mathrm{t}=1,034$ dan $p=0,308(p>0,05)$. Pengaruh positif ini dapat diartikan bahwa semakin tinggi konsentrasi kepemilikan maka pengungkapan tanggung jawab sosial yang dibuat perusahaan akan semakin luas.

\section{Pengaruh Dewan Komisaris Independen terhadap Pengungkapan Tanggung Jawab Sosial}

Ratnasari dan Prastiwi (2010) berpendapat bahwa keberadaan komisaris independen diharapkan dapat bersikap netral terhadap segala kebijakan yang dibuat oleh direksi.Keberadaan dewan komisaris independen tidak terpengaruh oleh manajemen, oleh karena itu mereka cenderung mendorong perusahaan untuk mengungkapkan informasi yang lebih luas kepada para stakeholder-nya.

Dalam penelitian ini komisaris independen yang diproksi dengan proporsi direktur independen dalam dewan komisaris, menunjukkan pengaruh yang negatif tidak signifikan terhadap pengungkapan tanggung jawab sosial perusahaan dengan nilai $\mathrm{t}=-1,097$ dan $p=0,280(p>0,05)$. Pengaruh negatif ini dapat diartikan bahwa semakin tinggi proporsi komisaris independen dalam dewan komisaris maka pengungkapan tanggung jawab sosial yang dibuat perusahaan akan semakin rendah. 
Temuan ini menjadi hal yang sulit untuk dijelaskan karena diharapkan bahwa komisaris independen akan memberi tekanan yang lebih besar untuk pengungkapan tanggung jawab sosial perusahaan. Akan tetapi, hasil penelitian yang sama juga ditemukan oleh Waryanto (2010) yang menemukan pengaruh yang negative tidak signifkan antara komisaris independen terhadap pengungkapan tanggung jawab sosial perusahaan. Temuan ini kemungkinan diakibatkan oleh pemilihan dan pengangkatan komisaris independen yang tidak efektif (FCGI, 2002 dalam Waryanto, 2010).Hal ini juga berarti bahwa dewan komisaris independen tidak mampu menunjukkan independensinya atau bahkan sebenarnya tidak independen.

Pernyataan dalam Kompasiana (Juni, 2015) berikut di bawah ini juga bisa jadi penyebab ketidakjelasan pengaruh komisaris independen terhadap pengungkapan tanggung jawab sosial.Di Indonesia, dinyatakan memang ada beberapa masalah terkait dewan komisaris perusahaan. Salah satu yang menjadi perhatian adalah adanya peran komisaris yang terlalu kuat dan ada pula peran komisaris yang lemah dalam melaksanakan fungsinya. Terjadi bias dalam pelaksanaan independensinya yang disebabkan oleh beberapa kecenderungan seperti peran komisaris yang terlalu kuat dalam perusahaan. Apabila ini terjadi , maka komisaris bisa menjadi terlalu mengintervensi direksi dalam menjalankan tugasnya. Sehingga efektifitas direksi dalam mengambil keputusan ynag bersifat teknis menjadi terhambat, bahkan bisa jadi tidak melibatkan direksi sama sekali dalam proses pengambilan keputusan perusahaan. Selain itu, adapula peran komisaris yang lemah dalam melaksanakan fungsinya. Hal ini, bisa disebabkan oleh beberapa faktor seperti kedudukan direksi yang sangat kuat, kompetensi dan integritas komisaris yang lemah, serta komisaris menduduki posisi yang sama di beberapa perusahaan.

Penelitian tentang tanggung jawab sosial perusahaan dalam dua dekade terakhir ini memang sudah begitu banyak dilakukan. Kebanyakan penelitian mengarah pada faktor faktor apa saja yang mempengaruhi luas pengungkapan tangung jawab sosial perusahaan dalam laporan tahunan. Penelitian terkait konten tanggung jawab sosial perusahaan masih cukup jarang, sehingga item pengungkapan yang digunakan belum ada yang baku.

Terkait dengan hasil penelitian juga sangat beragam.Banyak variabel yang sudah diuji sebagai faktor penentu pengungkapan tanggung jawab sosial perusahaan.Akan tetapi, hasil yang diperoleh masih sangat beragam.Tidak hanya masalah signifikansi pengaruh variabel tersebut, 
tetapi juga masalah arah dari pengaruh variabel tersebut terhadap pengungkapan tanggung jawab sosial perusahaan.Ada yang menemukan arah positif pengaruh satu variabel positif, tetapi ada juga yang menemukan arah yang negative.Kadang kadang secara logika teori pengaruh suatu variabel dinyatakan positif, tetapi hasil pengujian negative.

Hal tersebut di atas perlu menjadi perhatian yang lebih intens dari para pihak yang memberikan perhatian terhadap tanggung jawab sosial perusahaan.Selain itu, tentu saja kembali pada pihak perusahaan terkait motivasi dalam pelaksanaan tanggung jawab sosialnya.Hal ini perlu juga menjadi perhatian karena kadang kadang agak sulit membedakan antara kegiatan yang betul betul pelaksanaan tanggung jawab sosial dengan kegiatan promosi.Banyak juga kegiatan promosi yang dibungkus seolah olah itu merupakan tanggung jawab sosial.

Dari berbagai hasil penelitian, ada beberapa hal yang dapatdinyatakan sebagai faktor yang memotivasi perusahaan dalam melaksanakan tanggung jawab sosialnya, walaupun hal ini tentu saja masih bisa dikaji lebih lanjut. Yang terutama tentu saja adalah keberadaan regulasi dari pemerintah yang mewajibkan perusahaan melaksanakan tanggung jawab sosialnya terhadap stakeholder. Keberadaan regulasi ini akan sangat berpengaruh terhadap pelaksanaan tanggung jawab sosial perusahaan karena apabila tidak dilaksanakan, perusahaan akan dikenakan sanksi oleh pemerintah. Selain itu, perusahaan juga biasanya melaksanakan tanggung jawab sosialnya untuk meningkatkan nama baik dan reputasi perusahaan di masyarakat, sehingga dapat berpengaruh terhadap calon investor, dan kemungkinan perolehan keuntungan dalam jangka panjang.

Perbaikan masalah sosial yang dihadapi masyarakat karena keberadaan perusahaan, tentu saja menjadi faktor yang memotivasi perusahaan dalam melaksanakan tanggung jawab sosialnya. Perbaikan masalah sosial ini akan dapat menjaga kelangsungan perusahaan dalam jangka panjang. Hubungan yang baik antara masyarakat sekitar dengan perusahaan memang perlu menjadi perhatian karena selain sebagai pihak yang langsung bersinggungan dengan perusahaan, masyarakat sekitar juga merupakan penyedia tenaga kerja dan konsumen dari perusahaan.

\section{KESIMPULAN DAN SARAN}

\section{Kesimpulan}

a. Secara simultan variabel ukuran dewan komisaris, direktur independen, direktur perempuan, konsentrasi kepemilikan dan Komisaris 
independen mempunyai pengaruh yang signifikan tehadap pengungkapan tanggung jawab sosial perusahaan

b. Secara parsial hanya variabel Ukuran dewan komisaris yang berpengaruh signfikan terhadap pengungkapan tanggung jawab sosial peusahaan, sedangkan variabel direktur independen, direktur perempuan, konsentrasi kepemilikan dan Komisaris independen mempunyai pengaruh yang tidak signifikan.

c. Nilai $r$ square yang rendah, yakni sebesar 0,336 menunjukkan bahwa variabel lain yang tidak digunakan dalam penelitian ini mempunyai pengaruh yang lebih besar yakni $64,40 \%$ terhadap pengungkapan tanggung jawab sosial perusahaan.

\section{Saran}

Implikasi teoritis sebagai agenda penelitian yang akan datang dari temuan penelitian ini yakni tingkat $r$ square yang rendah menunjukkan bahwa variabel lain yang tidak digunakan dalam penelitian ini mempunyai pengaruh yang jauh lebih besar terhadap pengungkapan tanggung jawab sosial perusahaan, sehingga penelitian mendatang diharapkan menambahkan variabel lain dari corporate governance untuk menemukan suatu model yang lebih baik dalam pendugaan pengungkapan tanggung jawab sosial perusahaan. Demikian juga dengan item-item pengungkapan tanggung jawab sosial perusahaan hendaknya senantiasa diperbaharui sesuai dengan kondisi yang ada di masyarakat.

\section{DAFTAR PUSTAKA}

Arifin Sabeni (2002), “An Empyrical Analysis of The Relation Between The Board of Director's Composition an the level of Voluntary Disclosure", ProoceedingsFor The Fifth Indonesian Conference On Accounting, No. 5 pp. 46-57

Barako, D.G.; Hancock, P.; Izan, H.Y. (2006) Factors Influencing Voluntary Corporate Disclosure by Kenyan Companies.Corp. Gov. Int. Rev. ,14, 107-125.

Barnea, A., Rubin, A. (2010) Corporate Social Responsibility as a Conflict Between Shareholders. J Bus Ethics 97, 71-86 
Beasley, Mark S, (2001), "Relationships Between Board Characteristics and Voluntary Improvement in Audit Committee Composition and Experience", Contemporary Accounting Research, Winter, Vol. 18 No. 4 pp 545-570

Carter, D.; Simkins, B.; Simpson, W. Corporate Governance, Board Diversity and Firm Value.

Financ. Rev. 2003, 38, 33-53. Coller, P., and A. Gregory, (1999), "Audit Committee Activity and Agency Costs",Journal of Accounting and Public Policy, Vol 18 (4-5) pp 311-332

Cheng, E.C.; Courtenay, S.M.(2006).Board Composition, Regulatory Regime and Voluntary Disclosure.Int. J. Account. 41, 262-289.

Claessens, 2003, Corporate Governance and Development Focus, Global Corporate Governance Forum

Donnelly, R.; Mulcany, M. (2008) Board Structure, Ownership and Voluntary Disclosure in Ireland.Corp. Gov. Int. Rev., 16, 416429.

Eng, L.L.; Mak, Y.T. (2003).Corporate governance and Voluntary Disclosure.J. Account. Public Policy, 22, 325-345.

Imam Ghozali. (2002). Aplikasi Analisis Multivariate dengan Program SPSS, Semarang:Badan Penerbit Universitas Diponegoro.

Gray, R, Kouhy, R. and Lavers, S (1995), "Methodological Themes: Constructing AResearch Database Of Social And Environmental Reporting By UkCompanies", Accounting, Auditing andAccountability Journal, Vol. 8 No. 2,pp. 78-101.

Gray, R, Owen, D. and Maunders, K. (1987), Corporate Social Reporting: Accountingand Accountability, Prentice-Hall, London.

Hackston, David and Milne, Marcus J., (1996).“ Some Determinants Of Social AndEnvironmental Disclosures In New Zaeland Companies", Accounting, Auditingand Accountability Journal, Vol. 9, No. 1, pp. 77-108

Jensen, M. Value Maximization, (2002). Stakeholder Theory and the Corporate Objective Function.Bus. Ethics Quart.,12, 235-256.

Jensen, M., C., dan W. Meckling, 1976."Theory of the firm: Managerial behavior, agency cost and ownership structure", Journal of 
Finance Economic 3:305- 360, di-download dari http://www.nhh.no/for/courses/spring/eco420/jensenmeckling76.pdf.

Khan, (2011)The Effect of Corporate Governance Elements on Corporate Social Responsibility (CSR) Reporting: Empirical Evidence from Private Commercial Banks of Bangladesh. International Journal of Law and Management 52 (2).August 2011

L. L. Eng and Y. T. Mak(2003) Corporate governance and voluntary disclosure.. Journal of Accounting and Public Policy, , vol. 22, issue $4,325-345$

Mathews, M.R (1995). "Social and Environmental Accounting: A PracticalbbDemonstration of Ethical Concern", Journal of Business Ethics, Vol. 14, ppb663-671

Ratnasari, Yunita dan Prastiwi, Andri (2010) P engaruh corporate governance terhadap luas pengungkapan tanggung jawab sosial perusahaan di dalam sustainability report. Undergraduate thesis, Universitas Diponegoro.

Sadia Majeed, Tariq Aziz and Saba Saleem (2015) yang berjudul The Effect of Corporate governance Elements on Corporate social responsibility (CSR) Disclosure: An Empirical Evidencefrom Listed Companies at KSE Pakistan. International Journal of Financial Studie, ,3, 530-556

Said, Roshima., Yuserrie Hj Zainuddin., dan Hasnah Haron. 2009. "The Relationship between Corporate Social Responsibility and Corporate Governance Characteristics in Malaysian Public Listed Companies". Social Responsibility Journal.Vol. 5, No. 2, hal. 212-226

Sembiring, Eddy. R. (2006). Karakteristik perusahaan dan pengungkapan tanggung jawab sosial: studi empiris pada perusahaan yang tercatat di buersa efek Jakarta.JMAKSI Vol.6.

Sutedi, Adrian. 2012. "Good Corporate Governance”. Sinar Grafika. Jakarta

Totok Mardikanto, (2014) CSR (Corporate social responsibility) (Tanggung Jawab Sosial Perusahaan), Alfabeta, Bandung, 
Waryanto.(2010). Pengaruh Karakteristik Good Corpoate Governance (GCG) Terhadap Luar Pengungkapan Corporate Social Responsibility di Indonesia.Skripsi. Universitas Diponegoro.

Yunus Handoko, (2014) "Implementasi Social and Environmental Disclosure dalam Perspektif Teoritis" Jurnal JIBEKA,Vol.8 No.2, 